\title{
SUCCINYLCHOLINE AND ACETAZOLAMIDE (DIAMOX) IN ANAESTHESIA FOR OCULAR SURGERY*
}

\section{Arthur S Carballo m d}

SuCCINYLCHOLINE is the muscle relaxant of choice for tracheal intubation, and tracheal intubation is a requisite for a satisfactory general anaesthesia in intraocular surgery However, succinylcholine is known to increase intraocular tension In 1955 and 1957 there were reports in the literature of loss of vitreous occurring during surgery of the open eye when succinylcholine was used in anaesthesia, 1,2 with a resulting loss of vision Succinylcholine also represented a serious hazard to patients with glaucoma ${ }^{3-7}$

A study was undertaken in the Department of Anaesthesia of the Winnipeg General Hospital to determine whether previous administration of acetazolamide (Diamox) would prevent the dangerous rise in intraocular pressure accompanying the use of succinylcholine in anaesthesia If the results proved successful, then this valuable muscle relaxant could be safely employed in cataract extractions and corneal transplants, and in patients suffering from glaucoma

The most important factor determining the internal pressure of the eye is the aqueous humour, the hydrostatic pressure of the blood accounting for only one-quarter of the total intraocular tension Formed in the clliary processes behind the iris by a combination of diffusion and active transport, in which the enzyme carbonic anhydrase plays an important role, the aqueous fills the posterior chamber and leaves the eye by the canal of Schlemm (Fig 1) ${ }^{8-11}$

Rapid increases in intraocular pressure are due to interference with the outflow of the aqueous in most cases. The normal eye has a great capacity for compensating any increase in intraocular: pressure, simply by increasing the rate of outflow of the aqueous The osmotic pressure of the aqueous humour is higher than the osmotic pressure of the blood If we compare the composition of the aqueous with that of blood, we observe that while the amount of proten of the aqueous is as low as $002 \mathrm{gm} / 100 \mathrm{ml}$, and the glucose, urea, and bicarbonate concentrations are lower than in blood, those of the chlorides, sodium, and lactate are higher The aqueous is the only means of nutrition of the lens and cornea, since they are devord of blood supply ${ }^{12-14}$

The normal intraocular pressure has an accepted physiological range of 10 to $22 \mathrm{~mm} \mathrm{Hg}$ above atmospheric pressure. There is a variation of 2 to $3 \mathrm{~mm}$. $\mathrm{Hg}$ daily for each individual, the higher readings being obtained in the early hours of the morning, and the lower ones early in the evening Position also accounts for a difference of 2 to $3 \mathrm{~mm} \mathrm{Hg}$, the reading being higher duning recumbency than in a standing position ${ }^{15}$

"From the Department of Anaesthesia, Winnipeg General Hospital Presented in part at the annual meetıng of the Western Division, Canadian Anaesthetists' Society, March, 1965 
The respiratory movements also affect intraocular pressure Deep inspiration may lower it by as much as $5 \mathrm{~mm} \mathrm{Hg}$, while it is increased during expuration. The pulse beat produces a physiological oscillation of 1 to $2 \mathrm{~mm} \mathbf{H g}$. Variations in arterial blood pressure are reflected in small but rapıd changes in the ocular tension with a time delay of only one-tenth of a second. Obviously this is due to

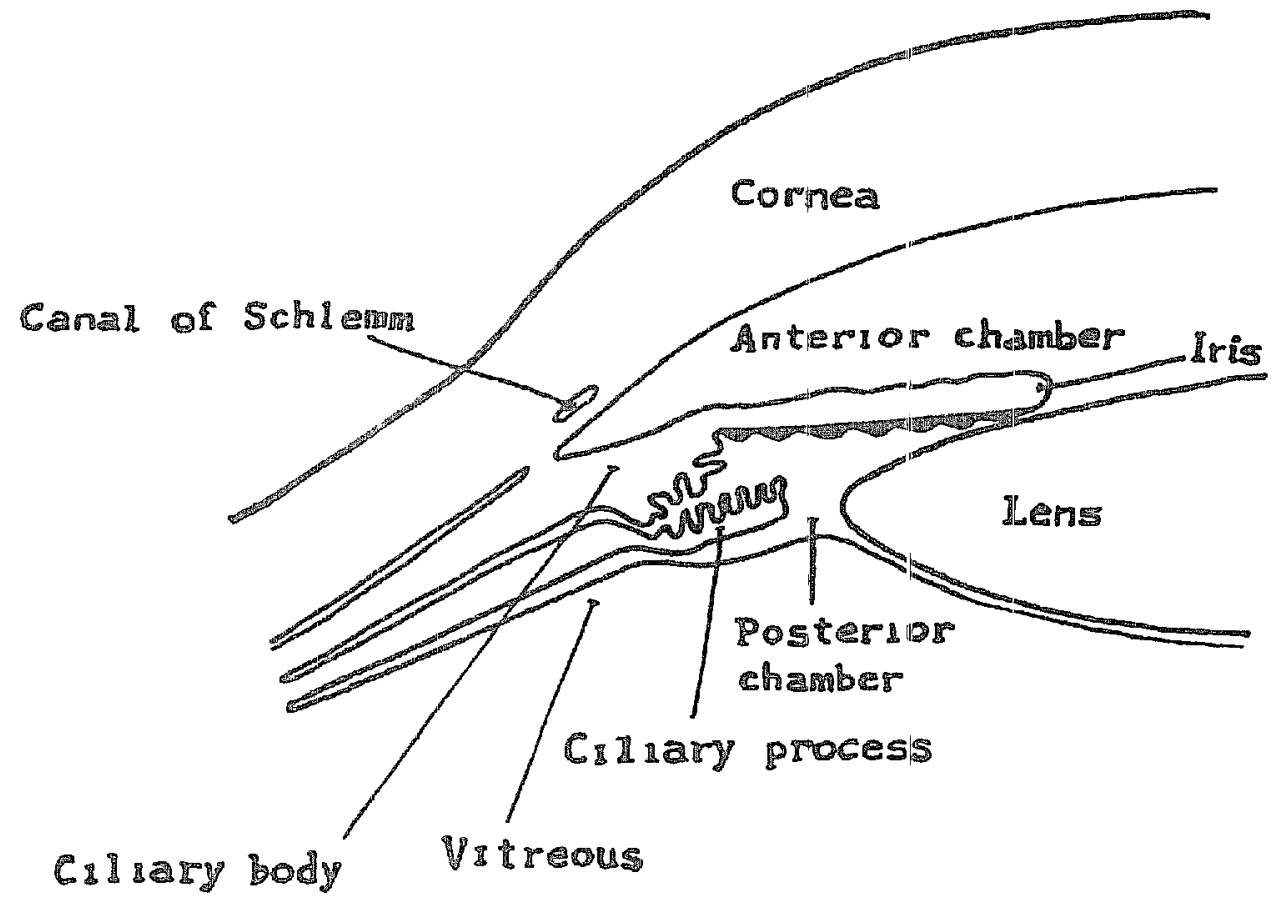

Ficure 1 The angle of the eyle

changes in the volume of blood curculating through the eye, and not to overproduction of aqueous humour In sustamed artenial hypertension, the ocular tension returns to its normal levels after a period of adaptation

Obstruction to the venous relurn from the head increases the ocular pressure, and so does coughing, sneezing, or straming This can be of importance during surgery of the open eye ${ }^{16} 17$

If the outhlow of the aqueous stops completely, the intraocular pressure should rise only to the effective filtration pressure of the capillary bed, which is about $30 \mathrm{~mm} \mathrm{Hg}$, and yet in closed angle glaucoma, readings above 80 and 90 have been reported It is interesting to note in this cornection that the hydrostatic pressure in the capillaries of the eye is $75 \mathrm{~mm} \mathrm{Hg}$, the osmotic pressure of the blood and the intraocular pressure being the only factors opposing it When the circulation stops at the moment of death the intraocular pressure falls to $5 \mathrm{~mm} \mathbf{H g}$ and stays at this level for a short period, then gradually drops to zero Hypoventilation, hypoxia, and hypercapnoea all elevate the tension in the eye On the contrary, hyperventilation, high oxygen tension, and hypocapnoea lower the intraocular tension Hypoprotennaemia has practically no effect 16

Endotracheal intubation by itself elevates the ocular pressure Retrobulbar anaesthesia and digital pressure on the eye are two very effective means in the hands of the ophthalmologist for reducing the intraocular pressure ${ }^{18-24}$

Rapid ingestion of one hitre of saline has no effect on the eye, but rapid ingestion of one litre of water elevates the pressure There is no agreement as to 
where control of the intraocular tensions hes, although the hypothalamus has been implicated The role of the sympathetic and parasympathetic fibres is also controversial 25-33

There are two methods of measuring intraocular pressure manometry, which involves placing a needle in the anterior chamber, and tonometry, used for recording the pressure necessary to depress the cornea Tonometers are based on two different principles indentation and applanation The first depends on the fact that the impressibility of the cornea depends mainly on the ocular tension, while the corneal rigidity plays but a minor role Indentation tonometers are surted for readings in the recumbent position The Schiotz's tonometer is the most commonly used Applanation tonometers are best used with the patient in the erect position ${ }^{34}$

Let us now review the effect of the anaesthetic agents on the intraocular pressure Cyclopropane, diethyl ether, chloroform, halothane, trichlorethylene, and divinyl ether lower the intraocular pressure The effect is more pronounced in deep planes of surgical anaesthesia, owing to the relaxation of the extraocular muscles and the consequent facilitation of aqueous outflow Ethylene does not alter the tension, and nitrous oxide has been reported to raise it ${ }^{28,35-39}$

Morphine, meperidine, and the short-acting and ultra-short-acting barbiturates lower the intraocular tension by facilitating the aqueous outflow Pre-anaesthetic medication at the usual doses of narcotic and atropine reduces the intraocular pressure of the normal eye by about 10 per cent ${ }^{16,21,28,29,40-42}$ Atropine alone, when given systematically, produces a slight rise in intraocular pressure, owing to capillary dilatation The concomitant mydriasis does not affect the normal eye, but in the patient with closed angle glaucoma it can produce an acute elevation of the intraocular pressure For this reason atropine has been indiscriminately withdrawn from the pre-anaesthetic medication of glaucomatous patients Actually it is only dangerous for the patient with narrow angle glaucoma ${ }^{37,43}$

There is no agreement as to the effects of scopolamine on the ocular pressure, but it is known to produce a greater degree of mydriasis than atropine Acetylcholine and the ant1-cholinesterases elevate the ocular tension by producing vasodilatation in the eye and by stimulating the contraction of the recti muscles Epinephrine in small doses elevates the intraocular pressure by stimulating only the beta receptors, while at higher concentrations it reduces the tension by means of vasoconstriction produced when the alpha receptors are also stimulated ${ }^{\text {44-47 }}$

Finally, the non-depolarizing muscle relaxants, curare and gallamine, relax the extraocular musculature, bringing the intraocular pressure down, while the depolarizing agents, decamethonium and succinylcholine, elevate it ${ }^{36,45,48-55}$

It has been accepted for some time that the mechanism of this elevation is a sustained contraction of the extraocular muscles, and that they react to succinylcholine in a fashion different from the other skeletal muscles While the latter suffer only momentary fasciculations followed by relaxation, the extraocular muscles respond with a sustained contraction, just as the belly muscles of birds and frogs do 1285253 56-61

Electromyography of the human extraocular muscles has demonstrated that the motor unit of these fibres is much smaller than that of the skeletal muscles 
and also that it is much simpler, so it can fire at greater frequency The innervation ratio of the soleus, for example, is 1 nerve filbre to 100 or 150 muscle fibres, compared to 15 for the extraocular muscles, and this ratio is characteristic of muscles used for precise and delicate movements Skeletal muscle at rest shows no recordable potential, while the extraocular muscles are seldom electrically

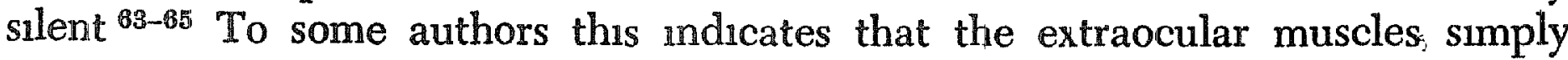
require a higher dose of succinylcholne to achieve the paralysis obtained in the skeletal muscle ${ }^{39}$

It has recently been shown that cutting the extraocular muscles does not prevent the rise in intraocular pressure caused by succinylcholine, and it is believed now that the direct vasodilatatory effect of the depolarizing muscle relaxant on the intrabulbar vessels is the main factor iesponsible for the rise in intraocular pressure, while the contracture of the extraocular muscles is only secondarily responsible ${ }^{66-68}$ Since the intraocular pressure is increased by succinylcholine, it seemed advisable to avoud its use during surgery of the open eye and in glaucoma Some authors found that the use of succinylcholine was only dangerous if it was administered after the eye was open Other investigators attempted to find a solution to this problem, some by using hexafluorenium (Mylaxen) to prevent the muscular fasciculations caused by succinylcholine, others by administering the drug very slowly, and still others by conducting the general anaesthesia in deep planes, or by injection of a local anaesthetic in the retrobulbar space and by applying pressure on the eye The greatest reductions in intraocular pressure were achieved by the use of hypertonic solution:s, thus intravenous Sorbitol, Dextran, and particularly urea and mannitol have been used with success in glaucoma ${ }^{1-520396568-76}$ For other publications on the subject, see references 91 to 123

Acetazolamide (Diamox) used intravenously is known to reduce intraocular pressure, starting to act within 2 minutes and reaching its greatest effect within 20 minutes This potent drug, decreasing the aqueous flow by 50 per cent, is easy to employ in comparison with the cumbeisome hypertonic solutions Acetazolamide has no action on the pupil, nor does it alter the outflow of the aqueous It completely mhibits the carbonic anhydrase activity of the ciliary body and uris, when given orally or intravenously The carbonic anhydrase inhibition goes hand in hand with a noticeable reduction in the ocular tension ${ }^{75}$ 77-89

Acetazolamide is a non-bacteriostatic sulphonamide derivative It produces diuresis and alkalinization of the urine, inducing a state of mild acidosis It results in renal loss of bicalbonate which carries with it water, sodium, and potassium This is the reason for its indication in oedema, congestive heart failure, and obesity In glaucoma it seduces the intraocular tension by slowing the rate of formation of aqueous humour It interferes with the elimination of carbon droxide by the lung, but this is of little concern, of course, in the anaesthetized panient whose respuations can be easily assisted It is contrandicated in renal acidosis, dehydration, and sodium or potassium depletion In large doses, or when given over long periods of time, it can produce drowsiness, disorientation, fever, leukopenia, and rashes But these will not occur when a single dose of $500 \mathrm{mg}$ is administered Acetazolamide in aqueous solution for intravenous use 
is alkaline, so care must be taken to avoid extravasation, but it produces no slough of the subcutaneous tissues. It pan be safely given intramuscularly $75,80,90$

\section{Ma terial}

The intraocular pressure of fifty anaesthetized patients was studied The subjects were chosen at random All were 20 years or older, and none of those included had glaucoma The surgical procedures, all of which gave easy access to the eye, are listed in Table I

TABLE I

Surgical Procedures Included in THE STUDY

\begin{tabular}{lc}
\hline \hline Surgical procedure & No of cases \\
\hline Ophthalmological & 7 \\
Gastro-intestinal & 32 \\
Orthopedic & 6 \\
E T & 3 \\
Urological & 2 \\
Total & 50 \\
\hline
\end{tabular}

\section{METHOD}

Pre-anaesthetic medication consisting of meperidine $50 \mathrm{mg}$ and atropine 06 mg was given intramuscularly one hour pre-operatively to each of the patients Induction of anaesthesia was carried out with sodium thiopentone in doses of 200 to $500 \mathrm{mg}$ to produce sleep In 25 of the 50 patients (the test group) induction was preceded by a rapid injection of $500 \mathrm{mg}$ acetazolamide dissolved in 5 to $10 \mathrm{ml}$ sterile distilled water The intraocular pressure was then measured with a Schiotz's tonometer with a $5 \mathrm{gm}$ plunger load Following this, the patient was oxygenated with a mask

Two minutes after acetazolamide had been administered, a second reading was taken Succinylcholine $60 \mathrm{mg}$ was given intravenously, and the lungs were inflated with oxygen $\mathbb{A}$ thrrd reading was recorded at the peak of the fasciculations of the muscles of the face Tracheal intubation followed, with manually controlled respiration using a mixture of oxygen at 3 litres per minute, nitrous oxide at 3 litres per minute, and halothane $\mathbb{A}$ circle absorber system using the semi-closed technique and a Fluotec vaporizer outside the curcle were employed in every case Ocular tensions were then recorded every minute for at least 5 times In the 25 patients not receiving acetazolamide (the control group), the intraocular pressure was taken after Pentothal induction and again two minutes later Then succinylcholne was given, and the reading repeated at the peak of facial fasciculations, and every minute from then on for at least 5 times Doses were as in the test group 


\section{Results}

The mean values of each successive group of 25 observations were calculated The standard deviations and upper limits were obtained for the basal tensions of the two series The successive readings were compared to the upper limits It was clear then that there were no significant deviations in the series with acetazolamide, but in the control series significant elevations over the upper limits were found in 19 out of the 25 observations made during fasciculations and in 17 out of the 25 made one minute later (Tables II and III) The mean estımates were obtained by adding all values obtained at similar moments and dividing the total by the number of observations. The standard deviations were obtaned by subtracting the mean from each reading, squaring each difference, summing the resulting squares, dividing by one less than the number of values and taking the square root Twice the standard deviation was added to mean estımate to give the upper limit, and subtracted to give the lower limit Figure 2 shows the mean estimates for both series

TABLE II

Intraocular Pressures, Control Series Protocol

\begin{tabular}{|c|c|c|c|c|c|c|c|}
\hline $\begin{array}{l}\text { Basal } \\
\text { IOP }\end{array}$ & $\underset{\text { later }}{2 \text { min }}$ & $\begin{array}{l}S \text { ch } \\
\text { fascic }\end{array}$ & $\begin{array}{l}1 \mathrm{~min} \\
\text { later }\end{array}$ & $\underset{\text { later }}{2 \min }$ & $\begin{array}{r}3 \mathrm{~min} \\
\text { later }\end{array}$ & $\begin{array}{r}4 \text { min } \\
\text { later }\end{array}$ & $\underset{\text { later }}{5 \mathrm{~min}}$ \\
\hline \multicolumn{8}{|c|}{ Recorded values } \\
\hline 146 & 122 & 206 & 189 & 173 & 173 & 146 & 146 \\
\hline 122 & 102 & 173 & 206 & 173 & 189 & 146 & 102 \\
\hline 173 & 173 & 244 & 244 & 206 & 146 & 173 & 159 \\
\hline 102 & 85 & 206 & 244 & 189 & 146 & 102 & 122 \\
\hline 122 & 122 & 244 & 244 & 173 & 189 & 146 & 102 \\
\hline 159 & $12 \sqrt{2}$ & 206 & 189 & 134 & 189 & 189 & 189 \\
\hline 189 & 189 & 244 & 206 & 206 & 159 & 146 & 146 \\
\hline 112 & 15. & 244 & 206 & 159 & 146 & 112 & 112 \\
\hline 159 & 17 & 266 & 290 & 189 & 146 & 146 & 146 \\
\hline 146 & 146 & 224 & 345 & 244 & 173 & 146 & 159 \\
\hline 173 & 159 & 189 & 189 & 173 & 173 & 146 & 146 \\
\hline 146 & 159 & 344 & 290 & 189 & 189 & 173 & 122 \\
\hline 134 & 159 & 159 & 159 & 146 & 159 & 159 & 146 \\
\hline 159 & 159 & 146 & 173 & 146 & 159 & 159 & 159 \\
\hline 146 & 159 & 206 & 189 & 146 & 146 & 146 & 146 \\
\hline 173 & 173 & 244 & 244 & 206 & 189 & 189 & 173 \\
\hline 102 & 102 & 146 & 173 & 134 & 134 & 112 & 112 \\
\hline 112 & 102 & 206 & 206 & 189 & 134 & 112 & 102 \\
\hline 206 & 189 & 290 & 266 & 206 & 146 & 146 & 146 \\
\hline 159 & 173 & 266 & 206 & 244 & 173 & 146 & 122 \\
\hline 173 & 189 & 345 & 266 & 206 & 173 & 189 & 159 \\
\hline 134 & 134 & 173 & 173 & 134 & 134 & 134 & 122 \\
\hline 134 & 134 & 244 & 266 & 173 & 122 & 122 & $12 \overline{2}$ \\
\hline 159 & 173 & 290 & 266 & 146 & 134 & 134 & 122 \\
\hline 173 & 173 & 290 & 266 & 189 & 189 & 189 & 189 \\
\hline \multicolumn{8}{|c|}{ Mean values } \\
\hline 148 & 144 & 231 & 227 & 178 & 160 & 148 & 138 \\
\hline
\end{tabular}

Standard deviation 274

Upper limit 2038

Lower limit 922 
TABILE III

Intraocular Pressures, Teq, Series Protocol

\begin{tabular}{|c|c|c|c|c|c|c|c|}
\hline $\begin{array}{l}\text { Basal } \\
\text { IOP }\end{array}$ & $\begin{array}{c}\text { Diamox } \\
\text { effect }\end{array}$ & $\begin{array}{l}S \text { ch } \\
\text { fascic }\end{array}$ & 1 min & 2 min & $\begin{array}{l}3 \mathrm{~min} \\
\text { later }\end{array}$ & $\begin{array}{r}4 \text { min } \\
\text { later }\end{array}$ & $\begin{array}{r}5 \mathrm{~min} \\
\text { later }\end{array}$ \\
\hline \multicolumn{8}{|c|}{ Recorded values } \\
\hline 159 & 159 & 189 & 189 & 189 & 173 & 102 & $12: 2$ \\
\hline 206 & 206 & 206 & 173 & 189 & 173 & 173 & 173 \\
\hline 173 & 159 & 159 & 173 & 159 & 159 & 159 & $15^{9}$ \\
\hline 206 & 206 & 173 & 189 & 173 & 159 & 159 & $17 ! 3$ \\
\hline 146 & 134 & 159 & 122 & 134 & 112 & 122 & 134 \\
\hline 173 & 173 & 173 & 173 & 159 & 159 & 102 & 122 \\
\hline 159 & 159 & 102 & 102 & 159 & 159 & 146 & 146 \\
\hline 173 & 159 & 173 & 189 & 146 & 159 & 173 & $17: 3$ \\
\hline 173 & 146 & 146 & 146 & 134 & 122 & 122 & 122 \\
\hline 102 & 122 & 122 & 85 & 102 & 59 & 71 & 59 \\
\hline 122 & 102 & 102 & 112 & 85 & 85 & 102 & 9,4 \\
\hline 122 & 102 & 112 & 94 & 94 & 112 & 102 & 122 \\
\hline 173 & 146 & 173 & 189 & 189 & 173 & 189 & 18,9 \\
\hline 102 & 71 & 146 & 173 & 146 & 122 & 146 & 146 \\
\hline 146 & 146 & 173 & 122 & 146 & 122 & 102 & 122 \\
\hline 122 & 122 & 85 & 85 & 102 & 122 & 122 & 122 \\
\hline 134 & 134 & 173 & 134 & 102 & 102 & 85 & 85 \\
\hline 146 & 102 & 122 & 146 & 102 & 122 & 122 & 122 \\
\hline 159 & 173 & 173 & 146 & 146 & 102 & 102 & 122 \\
\hline 173 & 159 & 189 & 159 & 159 & 159 & 173 & $17 \overline{3}$ \\
\hline 112 & 102 & 102 & 102 & 102 & 71 & 85 & 102 \\
\hline 102 & 102 & 122 & 122 & 85 & 102 & 102 & 102 \\
\hline 112 & 159 & 159 & 122 & 102 & 85 & 112 & $11 ; 2$ \\
\hline 134 & 134 & 102 & 122 & 122 & 102 & 122 & 122 \\
\hline 134 & $12 \overline{2}$ & $12 \overline{2}$ & 134 & 134 & 134 & 134 & 134 \\
\hline \multicolumn{8}{|c|}{ Mean values } \\
\hline 146 & 139 & 146 & 140 & 134 & 129 & 124 & 130 \\
\hline
\end{tabular}

Standard deviation 3059

Upper limit 2071

Lower limit 848

\section{Discussion}

Readings subsequent to those obtained within the five-minute interval proved to be unnecessary because in all cases observed the intraocular tensions did not revert to high readings after five minutes This fact has been repeatedly corroborated by previous publications of different authors who have found that the maximal effect of a single dose of succinylcholine on intraocular pressure occurs within twenty to thurty seconds and lasts from two to five minutes ${ }^{1,2}$

Although a perusal of Figure 2 may lead one to believe that the intraocular tension never rose after acetazolamide was given, 12 patients did show some rise in ocular tension after succinylcholine despite the carbonic anhydrase mhibitor, as can be seen in Table III But these elevations were not significant since they did not go above the calculated upper limits These results therefore appear to prove the significant value of acetazolamide as a means of preventing the elevations in ocular pressure produced by succinylcholine But if a practical conclusion has to be drawn from this study, the anaesthesiologist would do better administering the carbonic anhydrase inhibitor intravenously 20 to 30 minutes before the muscle relaxant, and limiting the succinylcholine dose to 20 or $30 \mathrm{mg}$ A more reliable control of the intraocular tension can be achieved in 
this manner The fact that glaucomatous patients have not been included in the study precludes extension of these conclusions to them

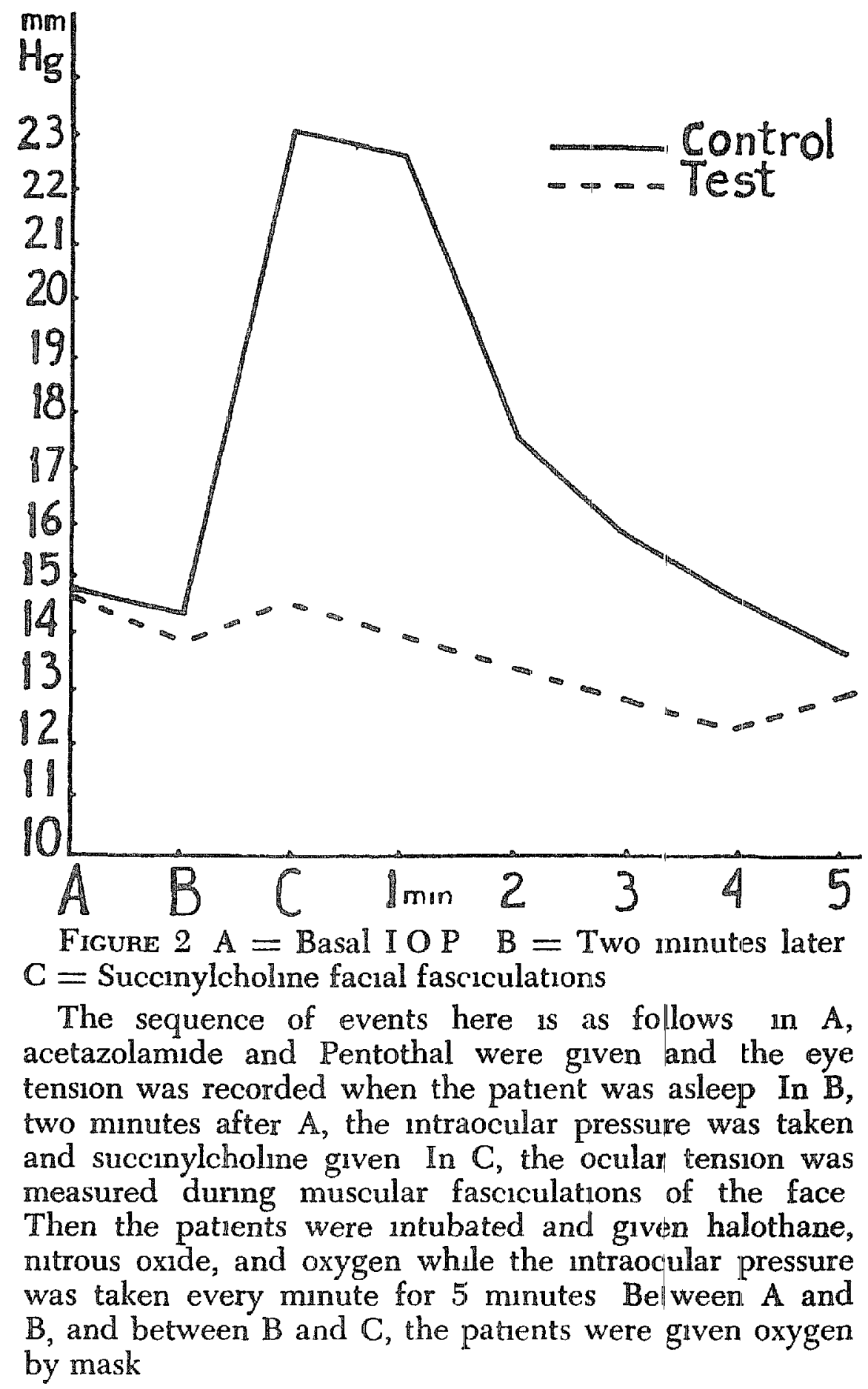

\section{SUMMARY}

A review of the physiology and pharmacology of intraocular pressure as related to anaesthesia has been presented A study has been undertaken to determine whether previously administered acetazolamide would prevent the dangerous rise in intraocular pressure accompanying the use of succinylcholine in anaesthesia, so that succinylcholine might be safely employed in cataract extractions and coineal transplants, and in patients suflering from glaucoma

The ocular tensions of two series of 25 anaesthetized patients, have bieen studied Acetazolamide (Diamox) and succinylcholine were given to the test group, and succinylcholine only to the control group The mean values of the successive readings, the standard deviations, and the upper and lower limits of the basal observations have been calculated The results are given in tables and the mean values are expressed graphically to facilitate their comparison 
Significant deviations have been found after succinylcholine alone, but not when acetazolamide was given before the succinylcholine The readings in the test group remained within the accepted normal limits for the intraocular tension

This study ther efore indicates the practıcal value of acetazolamide as a means of avoiding the significant elevations in intraocular tensions produced by succinylcholine

\section{Fúsumé}

Nous avons présenté une revue de la physiologie et de la pharmacologie de la pression intraoculaire en rapport avec l'anesthésie Nous avons entrepris une étude pour précıser si l'administratıon préalable d'acétazolamide (Diamox) pourrait prévenur l'élévation dangereuse de la pression intraocularre qui accompagne l'usage de la succinylcholine au cours de l'anesthésıe De cette façon, Il serait possible d'employer la succinylcholine, en toute sécurité, au cours de l'extraction de cataractes, de greffes de cornée et chez les malades qui souffrent de glaucome.

Nous avons étudié les tensions ocularres de deux séries de 25 malades anesthésiés Nous avons donné l'acétazolamide (Diamox) et la succinylcholine au groupe à l'étude et la succinylcholıne seule au groupe contrôlé Nous avons calculé les valeurs moyennes des lectures successives, les déviations standards, les limites supérieures et inférıeures des observations de base Nous donnons les résultats sur les tableaux et, pour faciliter leur comparaison, nous exprimons les valeurs moyennes par des graphıques Nous avons observé des variations importantes lorsque la succinylcholine était employée seule, mais non dans la série de sujets étudiés, chez qui l'acétazolamıde avait été donnée avant la succinylcholıne Chez ce dernier groupe, les lectures sont demeurées dans les limites normales acceptées pour la tension intraocularre

En conséquence, il semble bien que cette étude prouve la valeur pratique de l'acétazolamide (Diamox) comme inoyen d'éviter les élévations importantes intraocularres produrtes par la succinylcholine

\section{ACKNOWLEDGMENTS}

I am indebted to $\operatorname{Dr} D \mathrm{M} H \mathbb{H}$ uggins for her numerous suggestions and guidance, and to Drs $\mathbb{H}$ Reed and $K$ Grant for their invaluable co-operation

\section{REFERENCES}

1 Lincoff, H A, Breinin, G M, \& DeVoe, A G The Effect of Succinylcholine on the Extraocular Muscles Am J Opth 43440 (1947)

2 Schwartz, $H$ \& $D$ E RoETH, A Effect of Intraocular Pressure in Human Beings Anesthesiology $19112(1958)$

3 Atkinson, W S Anesthesia for Glaucoma Surgery New York J Med 56205 (1956)

4 Lewallen, W M \& Hrciss, B L The Use of Succinylcholne in Ocular Surgery Am $\int$ Ophth $49773(1960)$

5 Mietus, C A, Hague, E B, \& Carbone, D J Use of General Anesthesia and Muscle Relaxants in Cataract Surgery Am J Ophth 47487 (1959)

6 Rrwchun, $M$ H Choice of Anesthesla in Ophthalmic Surgery Anaesth \& Analg 37 75 (1958) 
7 Roche, J R Research in the Use of Curare for Ocular Surgery Am J Ophth 3391 (1950)

8 François, J, NeEtens, A, \& Colletre, J M Microradıographic Study of the Inner Wall of the Schlemm's Canal Am J Ophth 40491 (1955)

9 Friedenwald, I S Formation of the Intraocular Flurd Am J Ophth 329 (1949)

10 Friedenwald, J S \& Stiehler, R D Circulation of Aqueous vir A Mechanism of Secretion of the Intraocular Flud A M A Arch Ophth 20761 (1938)

11 Wrighr, S Apphed Physiology, 10th ed London Oxford Univ Press (1962)

12 AdLef, F H Physiology of the Eye Clinical Application, 3rd ed St Lous Mosby (1959)

13 - - Textbook of Ophthalmology, 7th ed Philadelpha Saunders (1962)

14 Kinsey, V E Comparative Chemistry of Aqueous Humour in Posterior and Anterior Chambers of Rabbit Eye A M A Arch Ophth 50401 (1953)

15 Galin, $M$ A \& Davidson, $R$ Diuretics in Ophthalmology New York J Med 62 $2831(1962)$

16 Duncalf, D \& Weitznen, S W Ventilation and Hypercapnea on Intraocular Pressure Anaesth \& Analg $42 \quad 232$ (1963)

17 MACRI, F J Vascular Pressure Relationships and the Intraocular Pressure A M A Arch Ophth 65571 (1961)

18 AtKinson, W S Local Anesthesia in Ophthalmology Am J Ophth 311607 (1948)

19 Becrer, B Annual Review of Glaucoma, 1955-1956 A M A Arch Ophth 56898 (1956)

20 Dei Przzo, A \& Guida, $F$ Succinylcholine in Catardct Surgery Anaesth \& Analg 40 $686(1961)$

21 Everett, W G, Vey, E K, \& Veenis, C Y Factors in Reducing Ocular Tension proor to Intraocular Surgery Tr Am Acad Ophth 63286 (1959)

22 Grifford, $H$ A Study of the Effect of Retrobulbar Anesthesia in the Ocular Tension and the Vitreous Pressure Am J Ophth 321359 (1949)

23 Kinsch, R E \& Steinman, W Digital Pressure, an Important Safeguard in Cataract Surgery A M A Arch Ophth 54697 (1955)

24 Snydacker, D, Deutsch, W E \& Bayard, W Vanous Anesthetic Agents Used in Retrobulbar Injections A M A Arch Ophth 51473 (1954)

25 Becref, B \& Chriestensen, R E Water Drinking and Tonography in the Diagnosis of Glaucoma A M A Arch Ophth 56321 (1956)

26 Galin, M A, Aizawa, F, \& McLean, I M Evaluation of the Water Provocative Test Am J Ophth 51451 (1961)

27 Gailn, $M$ A, Aizawa, F, \& Mcliean, J M The Water provocative Test in Glaucomatous Patients Am J Ophth 5215 (1961)

28 Kornblueth, W, Aladjemoff, L, Magora, F, \& Gabeay, A Influence of General Anesthesia on Intraocular Pressure in Man A M A Anch Ophth 61 84 (1959)

29 Schmert, E \& Strinberg, B Role of the Diencephalon in Regulating Ocular Tension Am J Ophth 31155 (1948)

30 - - Determination of Ocular Tension and Rigidity in Rabbits Am J Ophth 291400 (1946)

31 - - Central Control of Intraocular Pressure by Active Prnciples Am J Ophth 31 1097 (1948)

32 von Sallman, L, Macri, F J, Wanko, $T$, \& Grimes, $P$ a Some Mechanisms of Centrally Induced Eye Pressure Responses Am J Ophth 42130 (1956)

33 von Salimann, L \& Lovenstein Responses of Intraocular Pressure, Blood Pressure and Cutaneous Vessels to Electic Stimulation in the Diencephalon Am J Ophth $3911(1955)$

34 MOsEs, $\mathbb{R}$ A \& BECKer, B Clinical Tonography, The Scleral Rigidity Correction Am J Ophth 45196 (1958)

35 Adriand, J The Pharmacology of Anesthetic Drugs, 4th ed Springfield Thomas (1960)

36 Comroz, J $\mathrm{H}$ Jr \& Dripps, $R$ D Histamine-Like Action of Curare and Tubocurarine Injected Intracutaneously and Intraartenally in Man Anesthesiology $7 \quad 260$ (1946)

37 Magora, $F$ \& Collins, $V$ J The Influence of General Anesthetic Agents on Intraocular Pressure in Man A M A Arch Ophth 66808 (1961)

38 Schwartz, $H$ Chloroform Anesthesia for Ophthalmic Examination Am J Ophth 43 $27(1957)$ 
39 Wynands, J E \& Crowelt, D E Inlraocular Tension in Association with Succinylcholine and Endotracheal Intubation A Preliminary Report Canad Anaesth Soc J 739 (1960)

40 De Roetth, A Jr \& Schwartz, H Aqueous, Humour Dynamics in Glaucoma A M A Arch Ophth 55755 (1956)

41 Lund, P C Surital Soduum A New Intravenous Anesthetic Agent Am J Surg 81 $637(1951)$

42 Thomas, G J \& McCaslin, M F Pentothal Sodium in Ophthalmic Surgery A M A Arch Ophth 37452 (1947)

43 Gorm, A Medical Pharmacology, 1st ed St Louss Mosby (1961)

44 BARnetT, A Ocular Effects of Methonium Compounds Brit J Ophth 36593 (1952)

45 Colle, J C, Duke-Elder, $P$ M, \& Duke-Elder, W $S$ Studies on the Intraocular Pressure J Physiol 711 (1931)

46 Friedenwald, $J$ S \& Buschire, $W$ The Role of Epinephrine in the Formation of the Intraocular Fluid Am J Ophth 241105 (1941)

47 Leopold, I H, Hedges, $T$ R JR, Montana, J, \& Krishna, N Local Administration of Anticholinesterase Agents in Ocular Myasthenia Gravis A M A. Arch Ophth 63 $544(1960)$

48 Adamson, $\mathbb{D} \mathbb{C}$ \& Kinsman, $\mathbb{F}$ M Succinylcholine Chloride in Anaesthesia Anaesthesia 7166 (1952)

49 Agarwal, $\mathbb{L}$ \& Mathur, S $P$. Curare in Ocular Surgery Report of 25 Cases Brit J Ophth 36 603 (1952)

50 Bourne, J G, Collier, $H$ O J, \& Sommers, G F Succinylcholine (Succinoylcholine) Muscle-Relaxant of Short Action Lancet $1 \quad \mathbb{1 2 2 5}$ (1952)

51 von Dardel, O \& TheslefF, S Clinical Expenence with Succinylcholine Iodide A New Muscular Relaxant Anaesth \& An lg 31 250 (1952)

52 Dillon, I B, Sabawala, $\mathbb{P}$, Taylor, D B, \& Gunter, $R$ Depolarizing Neuromuscular Blocking Agents and Intraocular Piessure in Vivo Anesthesiology 18439 (1957)

53 _- Action of Succinylcholme on Extrajocular Muscles and Intraocular Pressure Anesthessology 1844 (1957)

54 Drucker, $\mathbb{P}$, SADOve, M S, \& UNiJA, K $\mathrm{R}$ Ophthalmic Studies of Curare and Curare-Iike Drugs in Man Am J Ophth 34543 (1951)

55 Harris, $L \mathbb{C}$ \& Dripps, $\mathbb{R} \mathbb{D}$ Use of Decamethonium Bromide for the Production of Muscular Relaxation Anesthesiology 11215 (1950)

56 Calvert, $R$ \& Morgan, $D \mathbb{K}$ Effect of Suxamethonium on Blood Pressure Anaesthesia 9196 (1954)

57 Craythorne, $\mathbb{N} \mathbb{W} \mathbb{B}$, Rottenstein, $\mathbb{H} S$, \& Dripps, $\mathbb{R}$ The Effect of Succinylcholne on Intraocular Pressure in Adults, Infants and Children during General Anesthesia Anesthesiology 2159 (1960)

58 Duke-Elder, S W \& Duke-Erder, $P$ M The Clinical Significance of the Ocular Musculature with Special Reference to the Intraocular Pressure and the Curculation of the Intraocular Fluid Brit J Ophth 16321 (1932)

59 Kinsey, $V$ E A Unified Concept of Aqueous Humour Dynamics and the Mantenance of Intraocular Pressure A M A Arch Ophth 44215 (1950)

60 Lincoff, H A, Ellis, C H, DeVoe, A G, \& De BeER, $\mathbb{E}$ The Effect of Succinylcholine on Intraocular Pressure Am J Ophth 40501 (1955)

61 Macri, F J Acetazolamide and the Venous Pressure of the Eye A M Arch Ophth $63953(1960)$

62 Breinin, G M \& Moldavir, J Electromyography of the Human Extraocular Muscles A M A Arch Ophth 54200 (1955)

63 Breinin, G M The Position of Rest During Anesthesia and Sleep Electromyographic Observations A M A Arch Ophth 57323 (1957)

64 Marg, E, Jampolsky, A, \& Tamlen, E Elements of Human Extraocular Electromyography $\mathbb{A}$ A Arch Ophth 61258 (1959)

65 Sober, A M Hexaffuorenium, Succinylcholine and Intraocular Tension Anaesth \& Analg 41399 (1962)

66 Waylin, A Clinical and Experimental Studies on Effects of Succinylcholine Acta Anaesth Scandinav Supplement v (Juhe, 1960)

67 WrETLAND, A \& WAHLIN, A The Effect of Succinylcholine on the Orbital Musculature of the Cat Acta Anaesth Scandinav 3.101 (1959) 
68 Camcron, A \& Bunn, R A Hexamethonium and Glaticoma Brit J Ophth 36482 (1952)

69 Clark, W B \& Duggan, J W The Use of Dibenamine in the Treatment of Acute Congestive Glaucoma Am J Ophth 34535 (1951)

70 Cordaro, V F \& ARnowwood, J G Mylaxen Prelimunary Clinical Evaluation of a New Agent for Neuromuscular Blockade Anaesth \& Andlg 34112 (1955)

71 Fajando, R V, Hamilon, R, \& Leopold, I H The Effect of Hydrochlorothiazide (Esıdrex) on Intraocular Pressure in Man Am J Ophth 491321 (1960)

72 Foldes, F F, Molloy, $\mathrm{R} \mathbf{E}$, Zsigmond, $\mathbf{E}$, \& ZwART, I $\mathbf{A}$ Hexafluorenium Its Anticholnesterase and Neuromuscular Activity J Phar|nacol Exper Therap 129400 (1960)

73 Foldes, $\mathbb{F}$, Hillmer, $\mathbb{N} R$, Molzoy, $\mathbb{R}$, \& MolNte, A $P$ Potentiation of the Neuromuscular Effect of Succinylcholine by Hexafluorentum Anesthesiology 2150 (1960)

74 Galin, M A, AIZAwA, F, \& McLean, J M Intravenous Urea in the Treatment of Acute Angle-Closure Glaucoma Am J Ophth 50379 (1960)

75 Galin, $M \AA$, McIvor, J W, \& Magruder, $G \mathbb{B}$ Inflience of Position in Intraocular Pressure Am J Ophth 55720 (1963)

76 Gartner, S Methods of Inducing Anesthesia and Hypotony for Cataract Surgery A M A Arch Ophth 6150 (1959)

77 ArRuga, H Diamox in Ophthalmology Arch Soc Ophth Hispano-am 15374 (1955)

78 Bartolozzi, $\mathbb{R}$ \& Garcis-Airx, $C$ Diamox in the Treatment of Glaucoma Preliminary Communication Arch Soc Ophth Hispano-am 15381 (1955)

79 BeCKer, $B$ Decrease in Intraocular Pressure in Man by a Carbonic Anhydrase Inhibitor, Diamox Am J Ophth 3713 (1954)

80 BECkER, B The Mechanism of the Fall in Intraocular lPressure by the Carbonic Anhydrase Inhibitor, Diamox Am J Ophth 39177 (1955)

81 Grant, W $M$ \& TrotTer, $\mathbb{R} \mathbb{R}$ Diamox (Acetazoleamide) in the Treatment of Glaucoma A M A Arch Ophth 51335 ( 1954)

82 Green, $\mathbb{H}$, Capper, Bocher, $\mathbb{C} \mathbb{A}$, \& Leopold, I $\mathbb{H}$ The Effect of Diamox on the Carbonic Anhydrase Activity of the Anterior Uvea of the Rabbit Eye AMA Arch Ophth 52758 (1954)

83 Green, $\mathrm{H}$, Bocher, C A, Calnan, A $\mathbb{E}$, \& Leopold, $\mathbb{I} \mathbb{H}$ Carbonic Anhydrase and the Maintenance of Intra Ocular Tension A M A Arch Ophth 53463 (1955)

84 Kronfield, $\mathrm{P}$ C \& Freeman, $\mathrm{H}$ M The Effect of Acetazolamide on the Response to Anterior Chamber Puncture in Man Am J Ophth 50 1141 (1960)

85 Langham, M E Specificity and Comparative-Activity of the Carbonic Anhydrase Inhibitors Neptazane and Diamox on Animal and Human Eyes Brit J Ophth 42 577 (1958)

86 Macin, $F$ J \& Grimes, $\mathbb{P}$ A The Effects of Succinylcholine on the Extraocular Stilate Muscles and on the Intraocular Pressure Am J Ophth 14 221 (1957)

87 SEARs, M L Intraocular Pressure of Unanesthetized Hen Lack of Response to Acetazolamide A M A Arch Ophth 63212 (1960)

88 - - Outflow Resistance of the Rabbit Eye Technique and Effects of Acetazolamide A M A Arch Ophth 64823 (1960)

89 Wistrand, $\mathbb{P}$ The Effect of Carbonic Anhydrase Inhibitor on Intraocular Pressure with Observations on the Pharmacology of Acetazolamide in the Rabbit Acta Pharmacol et Toxicol 16171 (1959)

90 Mutruatad, I F \& SCHEIE, $\mathbb{H}$ G Transient Myopta after Acetazolamide A M A Arch Ophth 63315 (1960)

91 AlFANO, I E \& CLAMPIT, I Injection of Hyaluronidase into the Anterior Chamber of the Rabbit Eye Am J Ophth 39198 (1955)

92 Arstizatis, $M$ \& Hongson, $H$ The Effect of Lobotomy and Electroshock on Intraocular Pressure Am J Ophth 353 (1952)

93 Becrser, B \& Fruedenwald, I S Clinical Aqueous Outflow A M A Arch Ophth 50 $557(1953)$

94 CASTLLO, J C \& DE BEER, E J Neuromuscular Blocking Action of Succinylcholine (Diacetylcholune) ] Pharmacol \& Exper Therap 99 4:58 (1950)

95 Condon, $\mathrm{H}$ A General Amesthesia in Ophthalmic Surgery But J Ophth $36 \quad 611$ (1952) 
96 Davson, H \& Spaziani, E The Fate of Substances Injected into the Anterior Chamber of the Eye J Physiol 151202 (1960)

97 De BeER, E J \& Castillo, J C Synthetic Drugs Influencing Neuromuscular Activity An New York Acad Sc1 54362 (1951)

98 DE Roetri, A JR Ophthalmic Pharmacology and Toxicology A M A Arch Ophth 64 292 (1960)

99 De Roetrm, A JR Ophthalmic Pharmacology and Toxicology A M A Arch Ophth 66277 (1961)

100 DuKe-Elder, $S$ W The Phasic Variations in the Ocular Tension in Primary Glaucoma Am J Ophth 351 (1952)

101 Ellis, C H , Whucis, A L, Fanelui, F V, \& De Beer, E Comparative Pharmacological Study of the Mono and Dichollae Esters of Succinic Acid J Pharmacol 109 83 (1953)

102 Foldes, F F, McNall, P G, \& Borriego-HinojosA, J M Succinylcholine A New Approach to Muscular Relaxation in Anesthesiology New England J Med 247 $596(1952)$

103 Lund, P C Clinical Evaluation of Succinylcholine Chloride as a Muscle Relaxant in Anesthesia Am I Surg $86 \quad 312$ (1953)

104 MAGEE, A I Electromyogram of the Extraocular Muscles of the Rabbit in Situ A M A Arch Ophth 52 212 (1954)

105 Mather, $\mathbb{R}$ W, Schuman, $\mathbb{C} \mathbb{R}, \&$ HAlRison, $S \mathbb{I}$ Influences of Curare and Eserine on Ocular Tension following Electroshock Am J Ophth 37859 (1954)

106 PAton, W D M \& Zaimis, $\mathrm{E}$ Actions and Clinical Assessment of Drugs which Produce Neuromuscular Block Lancet 2508 (1950)

107 Paul, S D \& LEOPOLD, I $\mathbb{H}$ The Eflect of Chlorpromazine on Intraocular Pressure in Experimental Animals Am J Ophth 42107 (1956)

108 GonzÁlez, C Topical Fludrocortisone (9-Alpha-Fluorohydrocortisone) in Ophthalmology Am J Ophth 49619 (1960)

109 Grant, W M Tonography in Chyonic Glaucoma New York J Med 56193 (1956)

110 Griffith, $\mathbb{R} \&$ Johinston, $G \mathbb{E}$ The Use of Curare in General Anaesthesia Anesthesiology 3418 (1942)

111 Howland, W S, Boyan, $\mathbb{C}$ P, \& Walng, $\mathbb{K} \mathbb{C}$ The Use of a Sterold (Viadril) as an Anesthetic Agent Anesthesiology 17 1 (1956)

112 Hunter, A $\mathbb{R}$ A Study of a New Relaxalnt Drug Anaesthesia 7 141 (1952)

113 Kennedy, $\mathbb{R}$ E Medical Treatment of Chromic Glaucoma New York J Med 56201 (1956)

114 Kinby, D B Use of Curare in Cataract Surgery A M Arch Ophth 43678 (1950)

115 Kornblueth, W, Jampolsky, $A$, TamLEF, $\mathbb{E}$, \& Marg, $E$ Contraction of the Oculorotatory Muscles and Intraoculdrr Pressure A Tonographic and Electromyographic Study of the Effect of $\mathbb{E}$ drophonium Chlornde (Tensilon) and Succinylcholine (Anectine) on the Intraocular Pressure Am I Ophth 491381 (1960)

116 LANDMESSE, $\mathbb{C} M$ A Study of the Bronchoconstrictor and Hypotensive Actuon of Curanzing Agents Anesthesiology 8506 (1947)

117 Linner, $\mathbb{E}$ \& $\mathrm{P}_{\mathrm{RIj}} \mathrm{T}, \mathbb{E}$ Cervical Sympathetic Ganglionectomy and Aqueous Flow A M A Arch Ophth 54831 (1955)

118 Schmerl, E \& Strenberg, $\mathbb{B}$ Separaltion of Diencephalic Cente is Concerned with Pupillary Motility and Ocular Tension Am J Ophth 331379 (1950)

119 Sears, M L \& BáRánY, E Outflow Resistance and Adrenergic Mechanisms A M A Arch Ophth 64839 (1960)

120 Stone, $\mathbb{H} H$ \& Prijot, $\mathbb{E}$ Effect of a Barbiturate and Paraldehyde on Aqueous Humour Dynamics in Rabbits A M A Arch Ophth 54834 (1955)

121 Tyner, G S \& SCHEIE, H G Mechanism of the Myotic-Resistant Pupll with Increased Intraocular Pressure A M Arch Ophth 50572 (1953)

122 Wistrand, $P$ \& Manen, $T H$ The Effect of Carbonic Anhydrase Inhibition on Intraocular Pressure of Rabbits with Different Blood $\mathrm{CO}_{2}$ equilibria Am J Ophth $50291(1960)$

123 Wnuck, $\mathbb{A}$ L, Nonton, $\mathfrak{s}$, \& Elis, $\mathbb{C}$ H Controlled Paralysis of Skeletal Muscle Anesthesiology $14 \quad 367$ (1953) 